of his work. He could have done more to highlight them. Most of Cousteau's first expeditions on the Calypso were predominantly scientific, and during the first years of his ownership she was the only French oceanographic ship, offering scientists the possibility of making direct observations down to 300 metres for the first time. Sponsored by the French National Centre of Scientific Research, his expeditions to the Mediterranean, the Red Sea and the Atlantic resulted in numerous publications, most of which are collected in the 11 volumes of the series Résultats Scientifiques des Campagnes de la Calypso, which contain important contributions to marine science. Cousteau was foremost an explorer, but his contribution to science was immense.

Jean Vacelet is a marine biologist at the Centre d'Océanologie de Marseille, Université de la Méditerranée, Marseille, France. He took part in several of the Calypso's scientific expeditions. e-mail: jean.vacelet@univmed.fr

\title{
Darwin's puppy love
}

\author{
Darwin's Dogs: How Darwin's Pets Helped \\ Form a World-Changing Theory of Evolution \\ by Emma Townshend \\ Frances Lincoln: 2009. 144 pp. \\ $\$ 14.95, £ 8.99$
}

and his letters home to his three older sisters are packed with affectionate banter about the animals. Writing of how much he missed his family's dogs, and in turn being told by his sisters how much the dogs missed him, was a face-saving way for a young man to admit his

Even the most ardent fan of Charles Darwin might be feeling weary as his anniversary year draws to a close. Publishers have seemingly explored every corner of Darwin's life: his youth, his marriage, his attitudes to slavery and religion. Emma Townshend adds a fascinating angle - Darwin's love of dogs. Dogs were Darwin's constant companions from boyhood to old age. They were also the animals closest to hand when he explored the implications of his theories. It is surely not coincidental that Darwin's credo was "it's dogged as does it".

In Darwin's Dogs, Townshend adds little new to the Darwin biography. Yet her close reading of his correspondence, filtered to references to the family's dogs, produces a warmer, more intimate portrait than others so far. She plausibly claims that, aside from his years at boarding school and on the aptly named ship HMS Beagle, Darwin spent every day of his life in the company of dogs.

Motherless at eight years of age and packed off to boarding school, the young Darwin had, by his own admission, a "passion" for dogs,

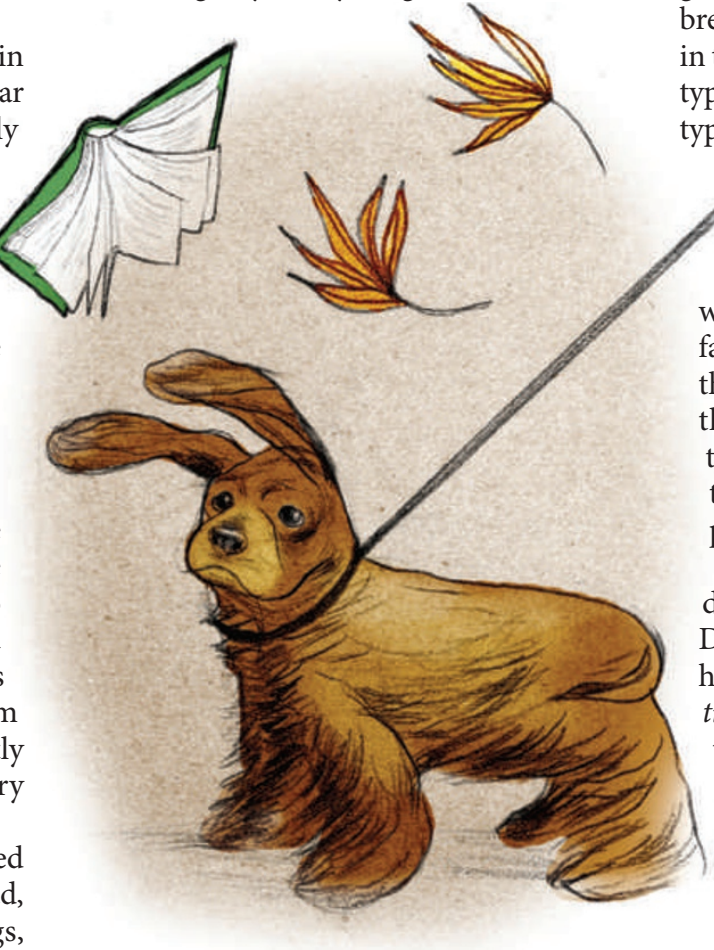

homesickness and exchange affection without embarrassment.

On his first morning back home after five years on the Beagle, Darwin went straight to the stables to see how his old "savage" dog, "averse to all strangers", would react to his return. Would the dog treat Darwin peaceably as befitted someone familiar, or would it growl at him showing that it had forgotten its master? As Darwin later recalled in The Descent of Man, the dog, "obeyed me, exactly as if I had parted with him only half an hour before. A train of old associations, dormant during five years, had thus been instantaneously awakened in his mind."

As Darwin's thoughts turned to 'transmutation' of species, the actions of dog breeders intrigued him. By carefully selecting those animals best suited to their purposes to form the parents of the next generation, breeders offered Darwin a metaphor - artificial selection - from which he could derive his great guiding principle of natural selection. Dog breeders were especially important to Darwin in trying to understand the sources of phenotypic variability and how varieties bred true to type - questions that were resolved long after Darwin's death.

The other major issue with which Darwin grappled on his return to the United Kingdom was that of finding a wife. There too, canine thoughts were never far from his mind. When he listed for himself the pros and cons of a married life, he noted the companionship of a wife to be "better than a dog, anyhow". In Townshend's narrative, we can see in this comment affectionate praise rather than insult.

On the Origin of Species opens with a discussion of domesticated animals. When Darwin came to his magnum opus on humankind, The Descent of Man, and Selection in Relation to Sex, dogs again have centre stage. Dogs, for Darwin, know happiness and sadness, grumpiness, kindness and loyalty. They understand language - Darwin pressed his neighbour, Sir John Lubbock, into testing the latter's dog's vocabulary - and they have a sense of humour. The

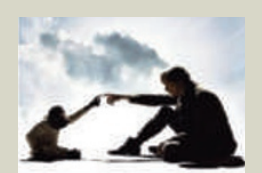
C REA T IO N
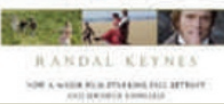

Creation: The True Story of Charles Darwin

by Randal Keynes (John Murray, £7.99)

Originally titled Annie's Box, Randal Keynes's renamed

and re-released book Creation focuses on Charles

Darwin's relationship with his daughter Annie and how her death subsequently affected his research. "Keynes weaves a rich tapestry that gives the reader a sense of the attitudes and assumptions of the Darwin family and their class," explained Bruce Weber in a review of the hardback edition of Annie's Box (Nature 411, 739-740; 2001).

\section{Strange Fruit: Why Both Sides Are Wrong in the Race Debate}

by Kenan Malik (Oneworld, E10.99)

The subject of race is often controversial but, Kenan Malik argues, we shouldn't avoid thinking about it. He attempts to describe what race is and is not, from a biological and cultural perspective, covering modern disputes such as the US approval of a drug for African Americans with heart disease. He also looks at historical views on race and its treatment today. 
concept of property ownership, Darwin argued, "is common to every dog with a bone". With a directness and candour that still shocks today, Darwin mused that a dog's "deep love ... for his master, associated with complete submission, some fear, and perhaps other feelings" prefigures human feelings of religious devotion.

Townshend shows a deft touch with a considerable body of Darwin scholarship. However, her simplified account of how scientific attitudes to dog behaviour have changed since Darwin is less secure. She mainly blames "behaviourists" in animal psychology for ruling inadmissible Darwin's sympathetic attribution of human qualities to dogs, noting that anthropomorphism has been reinstated in recent years by "cognitive psychologists". However, the rejection of anthropomorphism was not limited to behaviourists and encompassed all forms of animal-behaviour study in the mid-twentieth century. Debate over the degree to which scientific terms used to describe human behaviour can be applied to animals continues to this day.

All in all, Darwin's Dogs is thoroughly entertaining and informative. It is the ideal antidote to Darwin fatigue.

Clive Wynne is associate professor of psychology at the University of Florida, PO Box 112250,

Gainesville, Florida 32601, USA, and author of Do Animals Think?

e-mail:wynne@ufl.edu

\section{Forgotten treasure seeker}

The Fossil Hunter: Dinosaurs, Evolution, and
the Woman Whose Discoveries Changed
The World
by Shelley Emling
Palgrave Macmillan: $2009.256 \mathrm{pp}$.
$\$ 27, £ 15.99$
Remarkable Creatures
by Tracy Chevalier
Dutton/HarperCollins: $2009.352 \mathrm{pp}$.
$\$ 26.95 / £ 15.99$

Until recently, histories of science were written almost entirely by, for and about men. The nineteenth-century hunt for Jurassic-era fossils along the beaches of the British town of Lyme Regis was no different. Although the names of naturalists such as Georges Cuvier, William Buckland and Richard Owen who used the fossils to overturn society's ideas about life on Earth are familiar, that of Mary Anning is only beginning to be exhumed. The publication of two books about her life - one factual, one fictional - will raise her profile in the public imagination.

Anning was a poor, working-class twelve- year-old when she made her first major discovery within the rocks of the perilous sea cliffs in 1811: the first complete skeleton of an ichthyosaur. She went on to uncover many other important fossils, such as the first plesiosaur and the first complete skeleton of the winged reptile Dimorphodon macronyx. Collecting and selling small fossils to earn a living, she also led fossil hunts for naturalists visiting Lyme Regis.

Anning's discoveries made it into the local newspapers. But it was the wealthy collectors and the established naturalists championing her finds in the halls of the Geological Society whose names became associated with them. Although her fossils helped overturn the popular idea that Earth and all its inhabitants were created in six days in $4004 \mathrm{BC}$, paving the way for Charles Darwin's great synthesis in 1859, Anning wasn't mentioned in key publications or lectures.

In her diligent biography The Fossil Hunter, Shelley Emling explains that in Anning's day women had no place in the cut and thrust of science. Urged not to appear outdoors without a chaperone, women were barred from places where learned debates took place and were thought to lack the intellectual rigour or stamina for fieldwork. Despite this, women did make vital contributions. Anning shared the beaches of Lyme Regis with three other female fossil collectors - the middle-class Philpott sisters, notably Elizabeth, who made well-regarded finds. And Emling describes the activity of two other talented nineteenth-century women, the wives of geologists William Buckland and Roderick Murchison, whose contributions included sketching and labelling of geological samples on expeditions.

But Anning was more than a collector or helper - she was a true scientist. She reconstructed and cleaned her own finds. She devoured scientific articles, often painstakingly copying out the entire text and figures. She engaged in spirited discussions with the men who sought her expertise and her samples. She dissected living sea creatures on the kitchen table to better understand the anatomy of their longdead counterparts. She even conducted research, surmising, for example,

that the rock-like bodies she often found within the skeletons she uncovered - coprolites were hardened faeces. Together with William Buckland, she reconstituted coprolites in her workshop and deduced what the animals had been eating.

Like many retrospective narratives, Anning's story has its heroes and anti-heroes, set-pieces and eureka moments. In Remarkable Creatures, Tracy Chevalier uses these devices to construct a fictionalized account of Anning's life. Able to make things up when the details are shrouded in obscurity, Chevalier's engaging version easily wins out over Emling's more faithful biography. Chevalier's unconstrained hand lets one suspend disbelief, such as in "[Buckland] asked so many questions ... that I began to feel like a pebble rolled back and forth in the tide". By contrast, confined by the facts, Emling's wearing reliance on the conditional

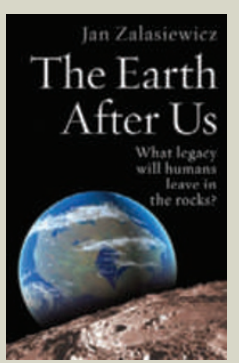

\section{The Earth After Us: What Legacy Will Humans} Leave in the Rocks?

by Jan Zalasiewicz (Oxford Univ. Press, $€ 8.99$ )

Using the imagined concept of extraterrestrial beings examining Earth for evidence that humanity ever existed, geologist Jan Zalasiewicz looks at what we might leave behind in the geological record. Describing the evidence we have for Earth's past, he explores our effects on the world and puts them in perspective over the vast timescale of the planet's history.
GILL MCKIBBEN

DEEP ECONOMY

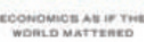
|||||||||||||

\section{Deep Economy: Economics as if the World Mattered} by Bill McKibben (Oneworld, $€ 9.99$ ) Bill McKibben calls for a new focus on developing local, rather than global, economies - advocating that cities and regions should produce more of their own food, energy and culture. Such small, local economies, he argues, offer a greater sense of community and satisfaction, and better protection against an increasingly uncertain future. 